\title{
Clinicopathological analysis of ovarian tumours: a 10 year retrospective study
}

\author{
Sahana N. Naik ${ }^{1}$, Sunil Kumar K. S. ${ }^{1 *}$, Girija B. ${ }^{2}$
}

\begin{abstract}
${ }^{1}$ Department of Obstetrics and Gynecology, Dharmasthala Manjunatheshwara College of Medical Sciences and Hospital, Dharwad, Karnataka, India

${ }^{2}$ Department of Obstetrics and Gynecology, Raichur Institute of Medical Sciences, Raichur, Karnataka, India
\end{abstract}

Received: 26 May 2018

Accepted: 26 June 2018

*Correspondence:

Dr. Sunil Kumar K. S.,

E-mail: drsuneelks@gmail.com

Copyright: (c) the author(s), publisher and licensee Medip Academy. This is an open-access article distributed under the terms of the Creative Commons Attribution Non-Commercial License, which permits unrestricted non-commercial use, distribution, and reproduction in any medium, provided the original work is properly cited.

\section{ABSTRACT}

Background: Ovarian tumors account for $30 \%$ of all cancers of female genital tract which represents the sixth most common cancer and fourth leading cause of death in women. The present study was done with an objective to determine the frequency and distribution of various ovarian tumors and to study their clinical and histopathological presentations.

Methods: It is a retrospective observational study of patients with ovarian tumors subjected to surgery in the department of obstetrics and gynecology, SDM College of Medical Sciences and Hospital from January 2005 to December 2015.

Results: There were 642 cases comprising of $77.7 \%$ of neoplastic lesions and $22.3 \%$ of non-neoplastic lesions. Majority of the ovarian tumors $(83 \%)$ were seen in the age group of 20 to 50 years. Mean age for ovarian tumors was 38 years. Among the neoplastic lesions $84 \%$ were benign, $14.2 \%$ were malignant and $1.8 \%$ were borderline tumors. Surface epithelial tumors were the commonest tumors $(60.9 \%)$ followed by germ cell tumors $(12.8 \%)$. Serous cystadenoma was the most common benign tumors $(47.1 \%)$ followed by mucinous cystadenoma (18.4\%). Among the ovarian malignant tumors; serous cystadenocarcinoma was the most common (4.5\%) followed by mucinous cystadenocarcinoma (2.6\%). Chocolate cysts were the most common among the non-neoplastic lesions (36.4\%).

Conclusions: Ovarian neoplastic lesions were more common than non-neoplastic lesions. Benign ovarian tumors were common in reproductive age group. The mean age of occurrence for ovarian tumor was 38 years. The most common neoplasm was surface epithelial tumors, of which serous tumors was the commonest. Chocolate cysts were the most frequently encountered histopathological finding among the non-neoplastic lesions.

Keywords: Histopathological types, Non neoplastic lesions, Ovarian tumors

\section{INTRODUCTION}

Ovarian masses with diverse histopathology are common forms of neoplasms in women and form one of the most challenging cases in Gynecology. Ovarian tumors account for $30 \%$ of all cancers of female genital tract. ${ }^{1}$ In most of the population based cancer registries in India, ovarian cancer is the third leading site of cancer among women trailing behind cervix and breast cancer. The age adjusted incidence rates of ovarian cancer vary between 5.4 and 8 per 100,000 populations in different parts of the country. $^{2}$

Ovarian tumors show histological heterogeneity. The classification of ovarian tumors by World Health Organization is based on the histogenesis of ovary. They are largely divided in to epithelial cell tumors, germ cell tumors, and sex cord stromal cell tumors. ${ }^{3}$ Determination 
of various histopathologic patterns of ovarian tumors is important in the management as well as prognosis. Benign ovarian tumors may occur at any point in life but they are more frequently found during childbearing age of 20 and 45 years, whereas malignant tumors are commoner in older women between the ages of 45 and 65 years. ${ }^{4}$ The inaccessibility of the ovaries for screening, complex nature with widely differing clinicopathological features, unpredictable behavior and prognosis poses a challenge to both gynaecologist and pathologist.

Imaging of the abdomen and pelvis helps to detect the origin, its complexity, its vascularity and spread to the adjacent structure but the definitive diagnosis of the tumor however is done by histopathological study. ${ }^{5}$ The present study was conducted with the aim of studying the histopathological pattern of ovarian tumors and their frequency in different age groups.

\section{METHODS}

This is a retrospective observational study of patients admitted with a clinical diagnosis of ovarian mass who underwent surgery in the department of obstetrics and gynecology, SDM College of Medical Sciences and Hospital, Sattur, Dharwad from January 2005 to December 2015.

\section{Inclusion criteria}

- All patients diagnosed to have ovarian mass that required surgery and their histopathology report was available

\section{Exclusion criteria}

- Patients with ovarian mass who did not undergo surgery.

Clinical data included age, history, clinical features, investigations and images, the type of surgery done and histopathological report. The lesions were categorized broadly into non-neoplastic and neoplastic lesions. The histopathological lesion of ovarian tumor was classified according to World Health Organization classification of ovarian tumors.

\section{Statistical analysis}

Descriptive statistics and Pearson Chi-square test were used to describe the study sample with Microsoft Excel software and IBM SPSS 20.

\section{RESULTS}

A total of 642 cases of ovarian tumors were studied and are as compiled in Table 1. Of which 499 (77.7\%) were neoplastic lesions and $143(22.3 \%)$ were non-neoplastic lesions. Among the neoplastic lesions, $83.8 \%$ were benign, $14.4 \%$ were malignant and $1.8 \%$ was borderline tumors.

Non-neoplastic lesions accounted for 143 cases (22.3\%) of which chocolate cysts were the most common 52 (36.4\%) followed by simple cyst $32(22.3 \%)$ as depicted in Figure 1.

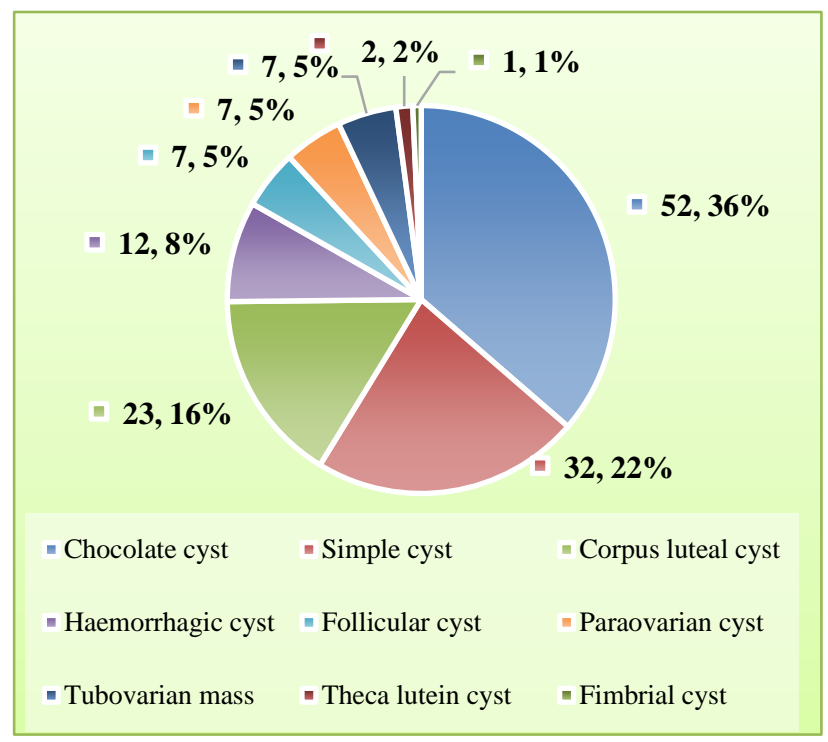

Figure 1: Distribution of non-neoplastic ovarian lesions.

Torsion of ovarian tumor was the most common surgical emergency accounting to 45 cases $(7 \%)$ which required immediate surgery. Simple cyst was the commonly found histopathological diagnosis among the ovarian torsion.

Table 1: Distribution of ovarian lesions.

\begin{tabular}{|ll|}
\hline Type of the ovarian lesion & No of cases \\
\hline Surface epithelial tumor & $391(60.9 \%)$ \\
\hline Germ cell tumor & $81(12.6 \%)$ \\
\hline Sex-cord stromal tumor & $25(3.9 \%)$ \\
\hline Secondaries & $2(0.3 \%)$ \\
\hline Benign lesions & $143(22.3 \%)$ \\
\hline
\end{tabular}

Ninety three percent of the ovarian tumors occurred in less than 60 years of age and $4.2 \%$ of the ovarian masses occurred in adolescent age group. Majority of the ovarian tumors $83 \%$ occurred between 20 to 50 years of age with the incidence of malignancy increasing with increase in age as shown in Table 2. Mean age of occurrence for all the ovarian lesions was 38 years.

Surface epithelial tumors dominated the neoplasms both in benign and malignant form accounting to $60.9 \%$ of the lesions followed by germ cell tumor $(12.8 \%)$ as shown in Table 3. Serous cystadenoma was the most common benign tumors $(47.1 \%)$ followed by mucinous cystadenoma $(18.4 \%)$. 
Among the malignant tumors serous cyst adenocarcinoma was the commonest $(4.5 \%)$ followed by mucinous cystadenocarcinoma after tumors, $(2.65 \%)$. There were 9 (1.4\%) borderline tumors in the study of which, 6 cases were borderline mucinous cystadenoma, 2 cases of borderline serous cystadenoma and one case of borderline Sertoli-Leydig cell tumor.

Table 2: Age distribution.

\begin{tabular}{|llllll|}
\hline Age (yrs) & Total & Benign & Malignant & Border-line & Secondary \\
\hline$<20$ & 27 & 27 & - & - & - \\
\hline $20-30$ & 181 & 170 & 8 & 2 & 1 \\
\hline $30-40$ & 176 & 163 & 7 & 5 & - \\
\hline $40-50$ & 148 & 130 & 18 & 2 & - \\
\hline $50-60$ & 70 & 49 & 19 & - & - \\
\hline$>60$ & 40 & 23 & 17 & & - \\
\hline
\end{tabular}

Germ cell tumors noted in 81 patients $(12.6 \%)$ of which $85.1 \%$ of them were benign mature cystic teratoma. There were total of 12 patients $(14.8 \%)$ of malignant germ cell tumor of which, 6 cases were diagnosed to have immature teratoma, 3 had dysgerminoma, 2 patients had yolk sac tumor and 1 patient had granulocytic sarcoma.

There were $25(3.9 \%)$ patients diagnosed to have sex-cord stromal tumors of which $18(72 \%)$ were benign, $6(24 \%)$ had malignant lesions and $1(4 \%)$ had borderline tumor.
Among the benign tumors there were 7 fibromas, 4 cases of granulosa cell tumor, 2 cases each of fibrothecoma, Sertoli-Leydig cell tumor and thecomas and 1 case of steroid tumor.

There was 1 case of borderline Sertoli-Leydig tumor. Out of the 6 malignant sex-cord stromal tumors, 4 patients had malignant granulosa cell tumor and 2 patients had malignant fibrothecoma.

Table 3: Distribution of the tumors arising from different layers.

\begin{tabular}{|llll|}
\hline Type of the tumor & Benign & Malignant & Borderline \\
\hline Surface epithelial tumors & $331(66.3 \%)$ & $52(10.4 \%)$ & $8(1.6 \%)$ \\
\hline Serous & $235(47.1 \%)$ & $29(5.8 \%)$ & $2(0.4 \%)$ \\
\hline Mucinous & $90(18.0 \%)$ & $17(3.4 \%)$ & $6(1.2 \%)$ \\
\hline Brenner & $4(0.8 \%)$ & $1(0.2 \%)$ & - \\
\hline Endometriod & - & $3(0.6 \%)$ & - \\
\hline Clear cell & - & $1(0.2 \%)$ & - \\
\hline Mixed mullerian tumor & - & $1(0.2 \%)$ & - \\
\hline Germ cell tumor & $69(13.8 \%)$ & $12(2.4 \%)$ & - \\
\hline Teratoma & $69(13.8 \%)$ & $6(1.2 \%)$ & - \\
\hline Dysgerminoma & - & $3(0.6 \%)$ & - \\
\hline Yolk sac tumor & - & $2(0.4 \%)$ & - \\
\hline Granulocytic sarcoma & - & $1(0.2 \%)$ & - \\
\hline Sex-cord stromal tumor & $18(2.8 \%)$ & $6(1.2 \%)$ & $1(0.2 \%)$ \\
\hline Fibroma & $7(1.4 \%)$ & - & - \\
\hline Granulosa cell tumor & $4(0.8 \%)$ & $4(0.8 \%)$ & - \\
\hline Fibrothecoma & $2(0.4 \%)$ & $2(0.4 \%)$ & - \\
\hline Sertoli-Leydig cell tumor & $2(0.4 \%)$ & - & $1(0.2 \%)$ \\
\hline Steroid tumor & $1(0.2 \%)$ & - & - \\
\hline Thecoma & $2(0.4 \%)$ & - & - \\
\hline Metastatic tumor & - & $2(0.4 \%)$ & - \\
\hline
\end{tabular}

\section{DISCUSSION}

Present study comprised of 642 cases of which $77.7 \%$ were neoplastic lesions and $22.7 \%$ were non-neoplastic lesions. Neoplastic ovarian lesions were more frequent than the non-neoplastic lesions in our study which was similar to other studies. ${ }^{6,7}$ About $85 \%$ cases were unilateral and $15 \%$ were bilateral. 
Among the ovarian neoplasms $84 \%$ were benign lesions, $14.2 \%$ were malignant and $1.8 \%$ was borderline tumors. These incidences of benign and malignant tumors were comparable to study by Yogambal et al and other studies. ${ }^{8-11}$ Some studies had higher incidence of benign tumors and some other studies had higher incidence of malignant tumors as in Mondal et al and Swamy et al compared to present study. ${ }^{9-11}$ The incidence of borderline tumors in present study was $1.8 \%$ which was comparable to other studies..$^{8,11-13}$

Maximum numbers of the ovarian tumors were seen in the age group of 20 to 50 years with benign lesions predominating in the age group of 20 to 40 years and malignant lesions in the age group of 40 to 60 years with increasing risk of malignancy beyond 40 years, which was similar to Wills $\mathrm{V}$ et al. ${ }^{14}$

The mean age of the occurrence of ovarian tumor was 38 years which was similar to Sheik et al, but it is much lower than the studies done by Mondal et al and Wasim et al who reported the mean age as 48 and 49.5 years respectively. ${ }^{10,13-15}$ A study by Murthy NS et al, involving data across various cities in India, revealed that the incidence of ovarian cancer increases from 35 years of age reaching its peak between 55-64 years. ${ }^{16}$ But the emphasis should be given to rule out malignancy in all age groups.

Since the ovary is a dynamic complex structure in embryology, histology, steroidogenesis with different components like germ cells, follicular cells, and mesenchymal tissue, the ovarian tumors show histological heterogeneity. Hence the classification of ovarian tumors by World Health Organization is based on the tissue of origin - epithelial, germ cell tumors, and sex cord stromal tumors. ${ }^{3}$

It is globally seen that; surface epithelial tumors are the most common ovarian tumors. In the present study authors also encountered surface epithelial tumors as the most common tumors followed by germ cell tumors. Among the benign tumor surface epithelial tumors $(66.3 \%)$ were predominantly high in our study which are comparable with other studies. ${ }^{8-16}$ Serouscystadenoma $(47.1 \%)$ was the most common histopathological type which was comparable to other studies, followed by mucinous cystadenoma similar to Shardha SO et al Germ cell tumors were the next common benign tumors with teratomas accounting up to $13.8 \% .^{7-16}$

Malignant tumors constituted $14.2 \%$ of which serous cystadenocarcinoma was the most common accounting up to $5.8 \%$ of the cases followed by mucinous cystadenocarcinoma $(3.8 \%)$ which was similar to other studies. $^{8,13,14}$

Germ cell tumors are the second most common group of ovarian neoplasms. They are the counterpart of testicular germ cell tumors. In the present study authors found 81 cases $(12.8 \%)$ of germ cell tumors which were consistent with other studies. ${ }^{9,17}$ Mature cystic teratoma was the most common among the germ cell tumor accounting for $84 \%$ of cases. Dysgerminoma are seen in 3 cases $(0.6 \%)$. There were 2 cases of yolk sac tumor and 1 case of granulocytic sarcoma.

Sex-cord stromal tumors represent approximately $7 \%$ of ovarian neoplasms. Sex cord stromal tumors arise from mesenchymal components like steroid producing cells as well as fibroblasts. They manifest as unilateral solid mass similar to testicular tumors. Hormonal changes are seen with estrogen producing granulosa cell tumors or testosterone producing Sertoli-Leydig cell tumors. Fibromas are inert hormonally but can produce complications like pleural effusion and torsion. ${ }^{18}$ In the present study authors could find about 18 (2.8\%) cases of benign sex cord stromal tumors. Out of that 7 patients had fibromas, 4 had granulosa cell tumour, 2 patients had fibrothecoma, 2 patients had Sertoli Leydig cell tumor, 2 patients had thecomas, and one patient had steroid tumor. Authors also had $6(0.9 \%)$ patients showing malignant sex cord stromal elements in the tumor. One patient had borderline sex cord stromal tumor.

Despite the rising incidence, morbidity and mortality due to ovarian malignancy, the etiology is poorly understood. Risk factors like age, family history and usage of drugs for ovulation induction has been well established. Uses of oral contraceptives, increasing parity, oophorectomy, hysterectomy, tubal ligation is considered to be protective factors. However, we couldn't find any statistically significant relationship with these factors in the present study. Recently there is a focus on fallopian tube as the site of origin of epithelial ovarian cancer. American College of Obstetrics and Gynecology in 2005 opined that prophylactic salpingectomy may offer protection instead of oophorectomy in women at risk for ovarian cancer. $^{19}$

Metastases to ovaries are relatively frequent with the spread most commonly from uterus, breast, colon, stomach and cervix. ${ }^{18}$ In present study there were 2 cases of secondary tumors, of which one was metastatis from medullary carcinoma of thyroid and the other from gastric carcinoma. Authors had 2 cases of synchronous endometriod carcinoma of ovary with endometriod carcinoma of uterus.

Authors had 3 cases with different tissue of origin in left and right ovary. One patient had right ovarian Brenner tumor with left ovarian fibrothecoma. Second patient had a left ovarian granulosa cell tumor with right ovarian cystadenoma and the third patient had a left ovarian mucinous cystadenoma with right ovarian fibroma.

Non-neoplastic lesions are the frequent cause of ovarian enlargement with possible hormonal activity of the follicles leading to follicular and luteal cysts or inactive serous cysts as classified by Blaustein. ${ }^{20}$ In present study 
chocolate cyst was the commonest $(36.4 \%)$ of the nonneoplastic tumor followed by simple ovarian cyst $(22.3 \%)$ similar to findings in the study by Will V et al. ${ }^{14}$ Twisted ovarian tumor is the most common gynecological surgical emergency. ${ }^{8}$ There were 12 cases of hemorrhagic cyst, 23 cases of corpus luteal cyst, 7 cases of paraovarian cyst, 2 cases of theca lutein cysts, 1 fimbrial cyst and 7 cases of tubo-ovarian masses.

Common clinical presentations among non-neoplastic lesions in this study were dysmenorrhea, abnormal uterine bleeding, infertility and vague pain abdomen. These findings are in similar to other studies by Ashraf et al, Sharada et al, Yogambal et al, Iyokec et al. ${ }^{7,9,21,22}$ Acute pain abdomen was the chief complaint in $7 \%$ of the patients and diagnosed to have torsion ovarian tumor that required immediate surgery. Dyspepsia, nausea vomiting, distension of abdomen and other gastrointestinal symptoms were seen more in patients with malignant ovarian tumors. There is often an immense difficulty in clinically distinguishing benign from malignant ovarian tumors using currently available diagnostic modality. Histopathology of ovarian tumors forms an integral part of the evaluation of the ovarian neoplasms in definitive diagnosis and predicting their prognosis. ${ }^{6}$

The limitation of the study is that present study is a single centric institution based retrospective study with a small group. Results of present study may not reflect the actual pattern and age distribution; a large multicentric approach is needed to compare present study results. Causative factors are not well analyzed. Due to limitation of the accurate data regarding survival in malignant ovarian tumors authors could not opine on prognosis.

\section{CONCLUSION}

Ovarian neoplasms had increased incidence when compared to non-neoplastic lesions. Ovarian tumors occurred more frequently in the reproductive age group of 20 to 50 years, with malignant lesions increasing with increase in age. Differentiation between a benign and malignant tumor is difficult many a times on imaging studies and histopathology is the only definitive way to confirm it. Based on the histopathology serous cystadenoma was the most common of the benign neoplasms and serous cystadenocarinoma was the commonest malignant neoplasm. Chocolate cyst was most frequently found ovarian enlargement among the non-neoplastic lesion.

\section{ACKNOWLEDGMENTS}

Authors would like to thank Dr. Dr. Col. U S Dinesh, Dr. Dr Umesh for their support during study.

Funding: No funding sources Conflict of interest: None declared

Ethical approval: The study was approved by the Institutional Ethics Committee

\section{REFERENCES}

1. Uma Devi K. Current status of gynecological cancer care in India. J Gynecol Oncol. 2009;20(2):77-80

2. Consolidated Report of Population Based Cancer Registries 2001-2004. National Cancer Registry Program Indian Council of Medical Research. Bangalore, 2006.

3. WHO classification of ovarian neoplasms. PathologyOutlines.com website. Available at: http://www.pathologyoutline.com/topic/ovarytumor whoclassif.html. Accessed May 21st, 2018

4. Day NE, Krishnan E. Epidemiology of gynaecological cancers. Gynaecology by Shaw R W. $2^{\text {nd }}$ ed. Edinburgh: Churchill Living Stone, 1997; 477-87.

5. Gentry-Maharaj A, Menon U. Screening for ovarian cancer in the general population. Best Practice Res Clin Obstetr Gynaecol. 2012;26(2):243-56.

6. Saxena HM, Devi G, Prakash P, Pankajam P. Ovarian neoplasms: a retrospective study of 356 cases. J Obstet Gynecol India. 1980;20(6):523-7.

7. Sharadha SO, Sridevi T, Renukadevi, Gowri R, Binayak D, Indra V. Ovarian Masses: Changing Clinico Histopathological Trends. J Obstetr Gynecol India. 2015;65(1):34-38

8. Yogambal M, Arunalatha P, Chandramouleeswari K, Palaniappan V. Ovarian tumours-Incidence and distribution in a tertiary referral center in south India. IOSR. J Dental Med Sci. 2014;13(2):74-80.

9. Mondal SK, Banyopadhyay R, Nag DR, Roychowdhury S, Mondal PK, Sinha SK. Histologic pattern, bilaterality and clinical evaluation of 957 ovarian neoplasms: a 10-year study in a tertiary hospital of eastern India. J Can Res Ther. 2011;7:433-7

10. Swamy GG, Satyanarayana N. Clinicopathological analysis of ovarian tumours: a study on five years samples. Nepal Med Coll J. 2010;12(4):221-3.

11. Mootha S, Dasari U. Clinico-pathological analysis of 100 ovarian tumours at a high-volume referral hospital. Int J Sci Res (IJSR).2015;4(1):238-41.

12. Soumini G, Sarella LK, Lakshmi Chaveli V, Gurugubelli S. Scenario of ovarian mass lesions at a teaching hospital in andhra pradesh India. Int $\mathbf{J}$ Reprod Contracept Obstet Gynecol. 2015;4:9829

13. Sheikh S, Bashir H, Farooq S, Beigh A, Manzoor F, Reshi R. Histopathological spectrum of ovarian tumours from a referral hospital in Kashmir valley, Jammu and Kashmir, India. Int $\mathbf{J}$ Res Med Sci. 2017;5(5):2110-4.

14. Wills V, Mathew R. A study on clinicohistopathological patterns of ovarian tumors. Int $\mathbf{J}$ Repr Contracept Obstetr Gynecol. 2017;5(8):266671.

15. Wasim T, Majrroh A, Siddiq S. Comparison of clinical presentation of benign and malignant ovarian tumours. J Pak Med Assoc Jan. 2009;59(1):18-21.

16. Murthy NS, Shalini S, Suman G, Pruthvish S, Mathew A. Changing trends in incidence of ovarian 
cancer- the Indian scenario. Asian Pac J Cancer Prev. 2009;10(6):1025-30.

17. Bhagyalakshmi A, Sreelekha A, Sridevi S, Chandralekha J, Parvathi G, Venkatalakshmi A. Prospective study of histopathological patterns of ovarian tumours in a tertiary care centre. Int $\mathbf{J}$ Res Med Sci. 2017;2(2):448-56.

18. Seiden MV. "Gynaecologic Malignancies". In Longo DL, Kasper DL, Jameson JL, Fauci AS, Hauser SL,Loscalzo J. Harrison's Principles of Internal Medicine (18 ${ }^{\text {th }}$ ed.). McGraw-Hill. 2012;810-813.

19. American College of Obstetricians and Gynecologists. Salpingectomy for ovarian cancer prevention. Committee opinion no. 620. Obstet Gynecol. 2015;125:279-81.

20. Blaustein A. Pathology of the female genital tract. $2^{\text {nd }}$ edition Springer 1982:449-463.
21. Ashraf A, Shaikh AS, Ishfaq AY, Akram AB, Kamal FU, Ahmad NA. The relative frequency and histopathological pattern of ovarian masses. Biomedica. 2012;28(1):98-102.

22. Iyoke CA, Ifeadike CO, Nnebue CC, Nkwo PO, Ezugwu EC, Edosuyi L, et al. A Ten-Year Review of Ovarian Cancer in Enugu, South East Nigeria. Afr Med J. 2011;2(1):8-12.

Cite this article as: Naik SN, Kumar SKS, Girija B. Clinicopathological analysis of ovarian tumours: a 10 year retrospective study. Int J Reprod Contracept Obstet Gynecol 2018;7:3216-21. 